\title{
Assumptions of good practices in home care for the elderly: a systematic review
}

\author{
Pressupostos das boas práticas do cuidado domiciliar ao idoso: revisão sistemática
}

Supuestos de buenas prácticas en la atención domiciliaria de las personas mayores: una revisión sistemática

\section{Rosalina Aparecida Partezani Rodrigues' ORCID: 0000-0001-8916-1078 \\ Alexandre de Assis Bueno' ORCID: 0000-0002-3311-0383 \\ Francine Golghetto Casemiro ORCID: 0000-0001-8932-3604 \\ Alan Nogueira da Cunha' ORCID: 0000-0002-5424-8947}

Lucas Pelegrini Nogueira de Carvalho ORCID: 0000-0002-5027-2042

Vanessa Costa Almeida' ORCID: 0000-0003-2126-8834

Nayara Araújo dos Reis' ORCID: 0000-0002-2611-4132

Fernanda Laporti Seredynskyj' ORCID: 0000-0001-7491-8891

Universidade de São Paulo. Ribeirão Preto, São Paulo, Brazil.

How to cite this article: Rodrigues RAP, Bueno AA, Casemiro FG, Cunha AN, Carvalho LPN, Almeida VC, et. al. Assumptions of good practices in home care for the elderly: a systematic review. Rev Bras Enferm. 2019;72(Suppl 2):302-10. doi: http://dx.doi.org/10.1590/0034-7167-2018-0445

Corresponding Author:

Rosalina Aparecida Partezani Rodrigues

E-mail: rosalina@eerp.usp.br

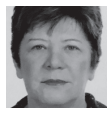

Submission: 06-10-2018

Approval: 09-09-2018

\section{ABSTRACT}

Objective: To synthesize the knowledge produced on best nursing practices in longterm care for elderly at home, in order to promote healthy aging. Method: A systematic review, based on the Joanna Briggs Institute's proposal: without restriction of dates; in the English, Portuguese and Spanish languages; conducted in PubMed, CINAHL, LILACS, Embase and Scopus databases. Results: Among 453 articles identified, 16 were included in the review: seven qualitative and nine quantitative, published between 1996 and 2015. The synthesis of the data identified as best practices identifies a premise of care centered on the elderly and the inclusion of the elderly, family and nurses as agents of this care. Conclusion: According to evidence, good practices in gerontological and nursing home care fundamentally depend on constant planning and reorganization, so that they are indeed comprehensive and contextualized. Thus, providing care will be reasoned by and driven to the elderly, based on their specific and global needs, favoring a process of healthy and active aging.

Descriptors: Health Services for the Aged; Home Care Services; Home Health Nursing; Geriatric Nursing; Review.

\section{RESUMO}

Objetivo: sintetizar o conhecimento produzido sobre as melhores práticas de enfermagem no cuidado de longa duração ao idoso no domicílio, a fim de favorecer o envelhecimento saudável. Método: Revisão sistemática, segundo proposta do Joanna Briggs Institute, sem restrição de datas, nos idiomas inglês, português e espanhol, nas bases de dados PubMed, CINAHL, LILACS, Embase e Scopus. Resultados: De um total de 453 artigos identificados, 16 foram incluídos na revisão: sete qualitativos e nove quantitativos, publicados entre 1996 e 2015. A síntese dos dados identificados como melhores práticas evidencia como pressupostos o cuidado centrado no idoso e a inclusão do idoso, da família e dos enfermeiros como agentes deste cuidado. Conclusão: As boas práticas em enfermagem gerontológica na atenção domiciliar, segundo as evidências, dependem fundamentalmente de constantes planejamentos e reorganizações, para que sejam de fato inclusivas e contextualizadas. Dessa forma, a produção do cuidado será fundamentada e orientada ao idoso, com base em suas necessidades específicas e globais, o que favorece um processo de envelhecimento saudável e ativo.

Descritores: Serviços de Saúde para Idosos; Cuidado Domiciliar; Enfermagem Domiciliar; Enfermagem Geriátrica; Revisão.

\section{RESUMEN}

Objetivo: Sintetizar el conocimiento producido sobre las mejores prácticas enfermeras en el cuidado a largo plazo para los adultos mayores en el hogar, a fin de promover un envejecimiento saludable. Método: Una revisión sistemática, basada en la propuesta del Instituto Joanna Briggs, sin restricción de fechas, en los idiomas inglés, portugués y español, realizada en las bases de datos PubMed, CINAHL, LILACS, Embase y Scopus. Resultados: Entre los 453 artículos identificados, 16 se incluyeron en la revisión: siete cualitativos y nueve cuantitativos, publicados entre 1996 y 2015. La síntesis de los datos se identificó como las mejores prácticas evidencian como premisas la atención centrada en los adultos mayores y su inclusión, así como de los familiares y enfermeras como agentes de este cuidado. Conclusión: De acuerdo con las evidencias, las buenas prácticas en gerontología y en asilos, dependen esencialmente de la planificación y reorganización constantes, por lo que son integrales y contextualizadas. Por lo tanto, la atención se razonará y se dirigirá a los adultos mayores, en función de sus necesidades específicas y globales, lo que favorece un proceso de envejecimiento saludable y activo. Descriptores: Servicios de Salud para Ancianos; Servicios de Atención de Salud a Domicilio; Cuidados de Enfermeira em el Hogar; Enfermería Geriátrica; Revisión. 


\section{INTRODUCTION}

The increase in the elderly population in developing countries has led to changes in the population pyramid. Epidemiological changes, characterized by reduction of infectious and parasitic morbidities, associated with the expansion of chronic noncommunicable diseases, are concomitant with this demographic transition. Even though there is a greater life expectancy of the population, other pathologies that can affect the autonomy and quality of life of the elderly occur ${ }^{(1)}$. Thus, it is necessary to reflect on the importance of care for the elderly throughout life, in order to provide a healthy and active senescence.

Long-term care can be provided in a variety of settings, including in the home, communities and Long-Term Care Institutions (LTC). In each of these, the caregiver has specific characteristics that are defined more by the dominant cultural model in a given society than by planning. Thus, when it comes to informal care, women are, in almost all societies, the main caretakers: an aspect that reinforces the role historically attributed to them, as well as doing housework and caring for other family members ${ }^{(2)}$.

However, regardless of the environment in which the individual elder's care is provided, and who promotes it, adequate preparation to deal with the specifics of this stage of life is necessary. It is also fundamental to encourage behaviors that favor the maintenance of autonomy and healthy aging, through the involvement of the family, health professionals and, above all, the elder in self-care, as well as the search for new creative practices ${ }^{(3)}$.

"Good practice", in Brazil, was officially stated in the Resolution of the Collegiate Board of Directors-RDC n०63 of 11/25/2011, which established the functioning of health services based on the principles of qualification, humanization of care, and the management, reduction and control of risks to the individuals and the environment ${ }^{(4)}$. This Resolution considers the care to the elder in the home to be a resource that enables humanization, controls the risks of disease transmission, and contributes to the maintenance of the elder's health in his own environment, as well as ensures care alongside his family. The proposals of this kind of care are different between countries, depending on current health policies and social conditions.

Therefore, performing the initial home visit to the elder is the responsibility of health professionals. It is an opportunity to plan care and define interventions that ensure good practices for this population, always with the concern of involving the family caregiver in this process, to guarantee social safety: of health, care, and other issues ${ }^{(5)}$. The family is responsible for taking care of the elder individual ${ }^{(6)}$, although the state must establish public policies that guarantee his rights and ensure adequate health care.

Health professionals should act as agents of societal transformation, and integrate the family in the care of the elder. One of the most effective manners to promote health, through the self-care practices developed by the elder individual, is to integrate him into different activities, such as health education interaction groups. Providing formal support is another behavior that transforms daily lives, contributes to coping with the changes inherent in the aging process, and minimizes the limitations imposed by the presence of chronic, noncommunicable diseases ${ }^{(7)}$. In addition, interaction groups can be a tool for social inclusion and interaction, in the sense of salvaging the autonomy and dignity of life, from the perspective of being and remain healthy ${ }^{(8)}$.
The home setting, and the many health services by which to approach the elder, using of multidisciplinary educational interventions, as well as the development of interaction groups, have been effective strategies for strengthening autonomy and independence for healthy aging ${ }^{(7)}$. Several other actions can be implemented in the information and communication era, so that health technologies (applications, for example) can be used by both the elder individual for self-care tasks, and by health professionals who accompany them in their homes. Thus, the use of technologies for diagnostics and therapeutics has increased in the scope of care for the elderly ${ }^{(9-10)}$.

Estimates suggest that in the next decade, long-term care will lead to significant changes in society, and so it is important that all health professionals use the benefits of such technologies carefully, and carefully reject those that harm the elderly ${ }^{(11)}$.

Population aging has become a challenge for public health, due to the high cost for health services, especially for elderly people, who have more demands for care. The greater meaning given to multiprofessional elder care, according to the new models of coping currently applied to overcome some of these challenges, the difficulty for finding qualified professionals to work in these types of care, and the lack of standardization in the care of this population, mainly at home, still constitute limitations of the Brazilian health system.

In view of the above, the objective of this study was to synthesize the knowledge of the best nursing practices in long-term care for the elderly at home, in order to promote healthy aging ${ }^{(12)}$.

\section{OBJECTIVE}

To synthesize the knowledge of the best nursing practices in long-term care for the elderly at home, in order to promote healthy aging.

\section{METHOD}

This was a systematic review, that followed the recommendations of the Joanna Briggs Institute (JBI), according to the nine steps recommended for the development of this type of study: 1 ) Development of the preliminary research protocol; 2) Formulating a review question; 3) Defining inclusion and exclusion criteria; 4) Search strategy; 5) Selecting studies for inclusion; 6) Assessing the quality of studies; 7) Extracting data; 8) Synthesizing data; 9) Narrative summary; 10) References and 11) Appendices ${ }^{(13)}$.

Initially, we selected studies that addressed the care provided by gerontological nursing in home care, aimed at the promotion of active and healthy aging. The studies identified reported the use of different strategies to care for the elderly population, both in Brazil as well as in other countries. We developed the guiding question based on the method proposed by the JBI, that is, we focused on the outcome of a given intervention for a population. In order to formulate the research question, we used the PICO strategy ${ }^{(14)}$; in this case we used:" "population" $(P)$, "intervention of interest" (I) and "outcome" (O). The "comparison" (C) was not applicable to this search. Finally, we defined the following research question:"Do good practices of gerontological nursing in home care and long-term care contribute to active and healthy aging?"

The following inclusion criteria were established: 1. Primary studies; 2. Periodicals published in Portuguese, English and / or 
Spanish language; 3 . Studies that described the nursing activities; 4. Studies on the care for the elderly at home; 5 . Studies reporting care for people 60 years of age or older; 6 . Studies on care provided that contributed to healthy aging.

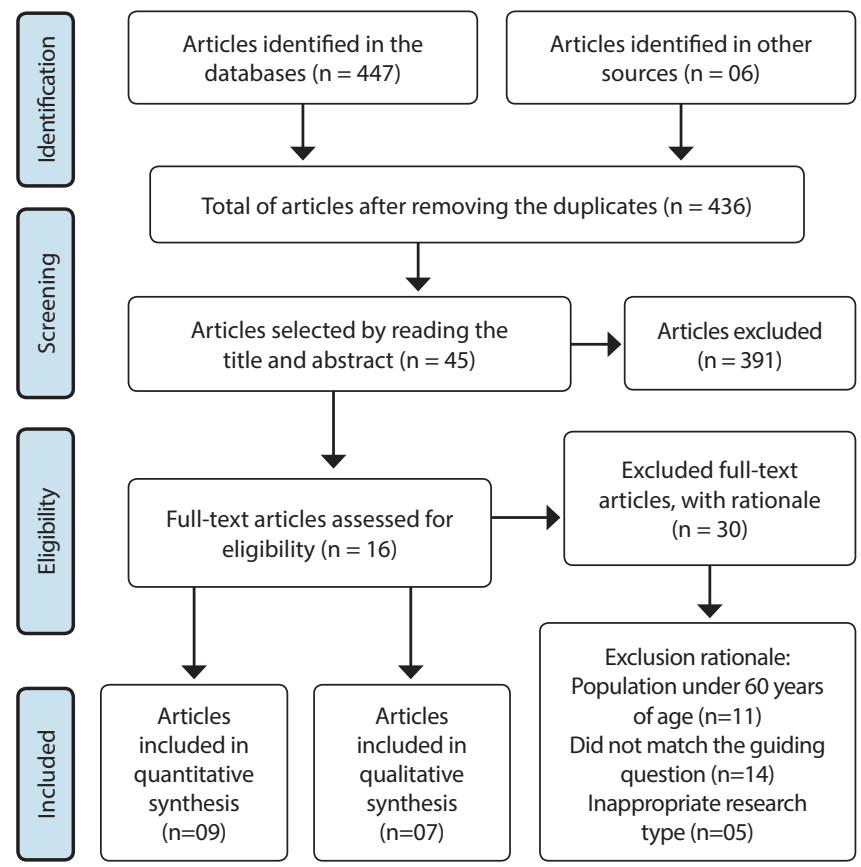

Figure 1- Selection of articles, PRISMA, 2018

The searches were conducted in April of 2018, in the following databases: National Center for Biotechnology Information (NCBI/PubMed), Cumulative Index for Nursing and Allied Health Literature (CINAHL), Excerpt Medical Database (EMBASE), Latin American and Caribbean Literature in Health Sciences (LILACS), and Scopus. We used the combination of controlled and uncontrolled descriptors, as indicated by each database. The articles in PubMed were accessed using Medical Subject Headings (MeSH) controlled descriptors; Heading-MH was used for the CINHAL database; for the search in EMBASE, we adopted the Embase Subject Headings (EMTREE); and the Health Sciences Descriptors (DeCS) were used to search within LILACS. For this search, we used "Long-term care", "gerontological nursing", "home care" and "healthy aging". We used the Boolean operator "AND" in all combinations as follows: "healthy aging AND gerontological nursing AND home care AND long-term care". We searched for articles in English, Spanish and Portuguese languages, and did not stipulate a time limitation for the publications. For selection of articles, we used the Rayyan application, developed by the Qatar Computing Research Institute (QCRI), which supports systematic reviews and facilitates the selection process of the studies. The reading of articles occurred in three stages: in the first, searches were conducted in the databases; in the second, three authors read the title and the abstract of the articles, in order to separate them for the next phase; and finally, in the third stage,

1 "Studies identified in other sources" refers to research published in scientific journals not indexed in the databases selected for this review.

"Inappropriate research type" encompasses non-primary studies that were only identified after reading the article in its entirety. we read the articles in their entirety, in order to select those that met the pre-established inclusion criteria for the final analysis ${ }^{(15)}$.

Throughout the process of searching for and selecting articles, we adopted the PRISMA protocol (Figure 1), with the intention of carefully planning and organizing the study and, thus, ensuring the development of a rigorous systematic review ${ }^{(16)}$.

As a reference for the analysis and extraction of data from the selected studies, we chose the instrument developed by Ursi (2006) (17). The results were organized by means of a descriptive synthesis of quantitative and qualitative data.

In this study, we analyzed public and free access articles, available in the databases of the scientific literature and, therefore, there was no need for submitting the study to the Research Ethics Committee in the CEP/ CONEP System, according to CNS Resolution 510/2016 ${ }^{(18)}$. We declare no conflict of interest in the execution of this review.

\section{RESULTS}

In the critical evaluation of the included articles (Chart 1), we considered the quality of studies adequate. Two of them did not specify the methodological framework used, and another one did not perform a sufficiently rigorous analysis of the data. On the other hand, the studies presented an adequate relationship between the proposed objectives and the research design, and described the results clearly, which contributed greatly to the understanding of the object of study.

The descriptions of the authors of the 16 articles were analyzed before the research question were reviewed, and separated according the type of research, that is, quantitative (9) or qualitative (7). The results were grouped into two stages, based on the analysis proposed in the study.

Chart 1 - Critical quality evaluation of included studies, 2018

\begin{tabular}{|l|c|c|c|}
\hline Question & Yes* & Partially & No* \\
\hline $\begin{array}{l}\text { 1. Was there a clear statement of the aims of the } \\
\text { research? }\end{array}$ & 16 & 00 & 00 \\
\hline 2. Is the methodology appropriate? & 14 & 02 & 00 \\
\hline $\begin{array}{l}\text { 3. Was the research design appropriate to address the } \\
\text { aims of the research? }\end{array}$ & 16 & 00 & 00 \\
\hline $\begin{array}{l}\text { 4. Was the recruitment strategy appropriate to the } \\
\text { aims of the research? }\end{array}$ & 16 & 00 & 00 \\
\hline $\begin{array}{l}\text { 5. Was the data collected in a way that addressed the } \\
\text { research issue? }\end{array}$ & 16 & 00 & 00 \\
\hline $\begin{array}{l}\text { 6. Has the relationship between researcher and the } \\
\text { participants been adequately considered? }\end{array}$ & 16 & 00 & 00 \\
\hline 7. Have ethical issues been taken into consideration? & 16 & 00 & 00 \\
\hline 8. Was the data analysis sufficiently rigorous? & 15 & 01 & 00 \\
\hline 9. Is there a clear statement of findings? & 16 & 00 & 00 \\
\hline $\begin{array}{l}\text { 10. How valuable is the research? } \\
\text { Note: Critical Appraisal Skills Programme(19) (CASP). }\end{array}$ & 16 & 00 & 00 \\
\hline
\end{tabular}

\section{Synthesis of Results of Quantitative Studies}

The quantitative studies included in the systematic review were published between 2004 and 2015 (Chart 2). All characterized the population investigated by collecting socio-demographic data (age, gender, and marital status) and highlighted two main themes: health education, and, program and care protocol. 
Chart 2 - Characterization of the nine quantitative articles analyzed, 2018

\begin{tabular}{|c|c|c|c|c|c|c|}
\hline \multirow{2}{*}{$\begin{array}{l}\text { Author/ } \\
\text { Year }\end{array}$} & \multirow{2}{*}{$\begin{array}{l}\text { Periodical } \\
\text { /country }\end{array}$} & \multirow{2}{*}{ Objective } & \multicolumn{4}{|c|}{ Method/Study } \\
\hline & & & Type & Variables & Intervention & Sample \\
\hline $\begin{array}{l}\text { Griffiths } s^{(20)} \\
\text { et al., } 2004\end{array}$ & $\begin{array}{l}\text { International } \\
\text { Journal of } \\
\text { Nursing Practice/ } \\
\text { Australia }\end{array}$ & $\begin{array}{l}\text { To analyze the effectiveness of } \\
\text { "community nurses" in improving } \\
\text { knowledge and self-management of } \\
\text { medications in a group of elderly people. }\end{array}$ & $\begin{array}{l}\text { Quasi- } \\
\text { experimental } \\
\text { study }\end{array}$ & $\begin{array}{l}\text { Medication self- } \\
\text { management }\end{array}$ & $\begin{array}{l}\text { Health } \\
\text { education }\end{array}$ & $\begin{array}{l}\text { Initial: } \\
184 \\
\text { Final: } \\
24\end{array}$ \\
\hline $\begin{array}{l}\text { Marek }^{(21)} \\
\text { et al., } 2006\end{array}$ & $\begin{array}{l}\text { Journal of } \\
\text { Nursing } \\
\text { Scholarship/ } \\
\text { USA }\end{array}$ & $\begin{array}{l}\text { To determine and compare the } \\
\text { impact of nursing care on patients in a } \\
\text { program. }\end{array}$ & $\begin{array}{l}\text { Quasi- } \\
\text { experimental } \\
\text { study }\end{array}$ & $\begin{array}{l}\text { General cognition, } \\
\text { medication self- } \\
\text { administration, } \\
\text { dyspnea, and pain }\end{array}$ & $\begin{array}{l}\text { Caring } \\
\text { program }\end{array}$ & $\begin{array}{l}\text { Initial: } \\
55 \\
\text { Final: } \\
30\end{array}$ \\
\hline $\begin{array}{l}\text { Park, } \\
\text { Kim } \\
2015\end{array}$ & $\begin{array}{l}\text { Public Health } \\
\text { Nursing/ South } \\
\text { Korea }\end{array}$ & $\begin{array}{l}\text { To evaluate the impact of a program } \\
\text { of home visits for hypertensive elderly } \\
\text { Koreans. }\end{array}$ & $\begin{array}{l}\text { A quasi- } \\
\text { experimental } \\
\text { study, with a } \\
\text { random sample, } \\
\text { without a control } \\
\text { group }\end{array}$ & $\begin{array}{l}\text { Knowledge about } \\
\text { arterial hypertension, } \\
\text { adherence to } \\
\text { medication, and } \\
\text { general self- } \\
\text { confidence in } \\
\text { treatment }\end{array}$ & $\begin{array}{l}\text { Health } \\
\text { education }\end{array}$ & $\begin{array}{l}\text { Sample: } \\
13,452\end{array}$ \\
\hline $\begin{array}{l}\text { Badia }{ }^{(23)} \text { et } \\
\text { al., } 2011\end{array}$ & $\begin{array}{l}\text { Gaceta } \\
\text { Sanitaria/ Spain }\end{array}$ & $\begin{array}{l}\text { To identify the characteristics of } \\
\text { chronic patients, to predict the nursing } \\
\text { workload. }\end{array}$ & $\begin{array}{l}\text { Cross-sectional } \\
\text { study }\end{array}$ & $\begin{array}{l}\text { Home visit } \\
\text { (dependent) } \\
\text { and chronic } \\
\text { characteristic } \\
\text { (independent) }\end{array}$ & $\begin{array}{l}\text { Health } \\
\text { education }\end{array}$ & $\begin{array}{l}\text { Initial: } \\
1068 \\
\text { Final: } \\
1002\end{array}$ \\
\hline $\begin{array}{l}\text { Villas } \\
\text { Boass } \\
\text { al., } 2012\end{array}$ & $\begin{array}{l}\text { Revista } \\
\text { Brasileira de } \\
\text { Educação } \\
\text { Médica/ Brazil }\end{array}$ & $\begin{array}{l}\text { To perform the home follow-up on the } \\
\text { elderly in the Family health unit }\end{array}$ & $\begin{array}{l}\text { Cross-sectional } \\
\text { study, with a } \\
\text { convenience } \\
\text { sample }\end{array}$ & $\begin{array}{l}\text { Activities of } \\
\text { daily living and } \\
\text { instrumental activities } \\
\text { of daily living }\end{array}$ & $\begin{array}{l}\text { Health } \\
\text { education }\end{array}$ & $\begin{array}{l}\text { Initial: } \\
15 \\
\text { Final: } \\
12\end{array}$ \\
\hline $\begin{array}{l}\text { Karlsson } \\
\text { (25) et al., } \\
2013\end{array}$ & $\begin{array}{l}\text { Journal } \\
\text { of Clinical } \\
\text { Nursing/ } \\
\text { Sweden }\end{array}$ & $\begin{array}{l}\text { To explore the satisfaction of home care } \\
\text { in relation to the place of residence, } \\
\text { functional dependence, and health } \\
\text { complaints among people } 65 \text { years of } \\
\text { age or older }\end{array}$ & $\begin{array}{l}\text { Cross-sectional } \\
\text { study }\end{array}$ & $\begin{array}{l}\text { Functional } \\
\text { dependence, health } \\
\text { complaints, and } \\
\text { quality of life }\end{array}$ & $\begin{array}{l}\text { Health } \\
\text { education }\end{array}$ & $\begin{array}{l}\text { Sample: } \\
166\end{array}$ \\
\hline $\begin{array}{l}\text { Markle- } \\
\text { Reid }^{(26)} \text { et } \\
\text { al., } 2006\end{array}$ & $\begin{array}{l}\text { Journal of } \\
\text { Advanced } \\
\text { Nursing/ } \\
\text { Canada }\end{array}$ & $\begin{array}{l}\text { To evaluate the comparative effects } \\
\text { and costs of a nursing promotion } \\
\text { intervention conducted by nurses, } \\
\text { together with the home care team. }\end{array}$ & $\begin{array}{l}\text { Randomized, } \\
\text { controlled, single } \\
\text { blind trial }\end{array}$ & $\begin{array}{l}\text { Cognition, } \\
\text { depression and } \\
\text { social support }\end{array}$ & $\begin{array}{l}\text { Health } \\
\text { education }\end{array}$ & $\begin{array}{l}\text { Initial: } \\
288 \\
\text { Final: } \\
288\end{array}$ \\
\hline $\begin{array}{l}\text { Moraes }^{(27)} \\
\text { et al., } 2013\end{array}$ & $\begin{array}{l}\text { Cogitare } \\
\text { Enfermagem/ } \\
\text { Brazil }\end{array}$ & $\begin{array}{l}\text { To verify the influence of the } \\
\text { application of a nursing protocol on } \\
\text { the prevention of pressure ulcers in the } \\
\text { elderly in home care. }\end{array}$ & $\begin{array}{l}\text { Experimental } \\
\text { randomized trial }\end{array}$ & Pressure ulcer & $\begin{array}{l}\text { Pressure Ulcer } \\
\text { Prevention } \\
\text { Protocol (UPP) }\end{array}$ & $\begin{array}{l}\text { Initial: } \\
520 \\
\text { Final: } \\
40\end{array}$ \\
\hline $\begin{array}{l}\text { Cooper }{ }^{(28)} \\
\text { et al., } 2011\end{array}$ & $\begin{array}{l}\text { Public Health } \\
\text { Nursing/ } \\
\text { USA }\end{array}$ & $\begin{array}{l}\text { To evaluate the impact of a program } \\
\text { on the care of individuals with chronic } \\
\text { disease }\end{array}$ & $\begin{array}{l}\text { Longitudinal } \\
\text { study with a } \\
\text { convenience } \\
\text { sample }\end{array}$ & $\begin{array}{l}\text { Knowledge about } \\
\text { chronic diseases }\end{array}$ & $\begin{array}{l}\text { Health } \\
\text { education }\end{array}$ & $\begin{array}{l}\text { Initial: } \\
55 \\
\text { Final: } \\
55\end{array}$ \\
\hline
\end{tabular}

In health education ${ }^{(20-22)}$, the variables investigated were related to aspects of daily life of the elderly individuals, such as medication administration and adherence, depression, social support, and knowledge about chronic diseases.

In the program and care protocol(21-22), the following themes were emphasized: cognition, self-administration of medication, dyspnea, pain, cutaneous integrity, functional dependence, health complaints, quality of life, knowledge, and adherence to treatment for arterial hypertension.

The objectives of the quantitative studies were the impact analysis of the nurse home visit, with regard to self-care promotion for elderly individuals with chronic, non-communicable diseases.

The methodological delineations described in the research differ, but we identified a predominance of quasi-experimental ${ }^{(20-22)}$ and transversal studies ${ }^{(23-25)}$, as well as experimental ${ }^{(26-27)}$ and longitudinal studies ${ }^{(28)}$.

With regards to the results, the authors stated that educational interventions could be considered a good practice to be promoted by nurses, who provide care for elders in home care, as well as an instrument that favors the adoption of other good care practices for their daily lives. The effectiveness of these interventions was evidenced both in the improvement of self-care of the elderly, and in the nursing care provided, so that their impact can be attributed to specific nursing interventions.

Such studies have described satisfactory outcomes for pain management, adherence to health promotion groups, awareness of attitudinal change, medication self-management, pressure injury prevention, knowledge of chronic diseases (hypertension, 
for example), medication adherence, self-confidence in treatment, cognition, dyspnea, pain, depression, social support, and improvement in basic activities of daily living and instrumental activities.

\section{Synthesis of Results of Qualitative Studies}

With regards to the qualitative articles, seven studies were included, published in Brazilian and Portugal periodicals between 2009 and 2013, five of them performed in Brazil ${ }^{(29-33)}$ and two in Portugal ${ }^{(34-35)}$. The general characteristics of these studies can be seen below (Chart 3).

In relation to our objective to identify some assumptions for good practices, the qualitative studies analyzed presented relevant topics: health education, support network, environment, specific needs of the elderly during the process of senescence and senility, self care, family, relationship, and health professionals. These are themes that, although they do not represent the good practices themselves, are characterized as guidelines for their composition.

The studies presented in Table 3 indicate the predominant use of the interview as a tool for data collection ${ }^{(29-32)}$, but add other forms, such as documentary analysis ${ }^{(31)}$, participant observation ${ }^{(29)}$, data recording ${ }^{(33)}$ and photovoice ${ }^{(35)}$. This latter is a method of data collection conducted in a more participative manner, as the subjects of the research are manifested by identification of images that best represent their positions in relation to the subject investigated, and present their own interpretations about the meanings of this relationship.

With regard to analysis, the use of exhaustive reading, coding, and identification of the related categories was predominant ${ }^{(29,31-}$ ${ }^{32,35)}$, an analysis process that is equivalent to thematic content analysis. However, one of the studies opted for content analysis by three independent experts ${ }^{(35)}$, so that the findings could be validated with greater rigor. One of the publications used the discourse of the collective subject ${ }^{(30)}$, and another incorporated a qualitative data analysis software ${ }^{(34)}$, confirming the strong tendency to use technological resources in this type of study.

The articles analyzed presented categories that can support the planning of home care for the elderly based on good practices. The results were grouped into four categories: object, instrument, purposes, and agents. These topics are identified as components of the health work process that can guide the development of good practices in gerontological nursing during specific actions, such as home care. Therefore, we can observe a direct relationship between the identified need, the work to be performed, and the organization of health service. The need identified in the review is the elderly patient who is at home. The work to be performed is nursing care, and the organization of the service signifies home care. Thus, the synthesis of findings presented in this review enables us to identify aspects that are related in practice, in a dynamic and continuous interaction, in development of good practices in gerontological home care nursing.

\section{DISCUSSION}

This analysis enabled the identification of good actions developed by nurses in the context of home care for elderly individuals, as well as the participation of the family in this process. Quantitative and qualitative studies refer us to successful experiences, which need to be encouraged and included in nurses gerontological practice.

The quantitative studies report different actions in the care provided to the elderly. Good health practices have been described as an important tool for promotion of active aging, for strengthening the autonomy and independence of the elderly, as well as for exercising a biopsychosocial impact.

Chart 3 - Characteristics of the seven qualitative articles analyzed, 2018

\begin{tabular}{|c|c|c|c|c|c|}
\hline \multirow{2}{*}{ Author/Year } & \multirow{2}{*}{ Periodic/ Country } & \multicolumn{3}{|c|}{ Method } & \multirow{2}{*}{$\begin{array}{c}\text { Assumptions of good } \\
\text { practices }\end{array}$} \\
\hline & & Referential & Data collection & Data analysis & \\
\hline $\begin{array}{l}\text { Rodrigues }^{(29)} \\
\text { et al, } 1996\end{array}$ & $\begin{array}{l}\text { Acta Paulista de } \\
\text { Enfermagem/Brazil }\end{array}$ & $\begin{array}{l}\text { Action } \\
\text { Research }\end{array}$ & $\begin{array}{l}\text { Participant observation } \\
\text { and semi-structured } \\
\text { interview }\end{array}$ & $\begin{array}{l}\text { Thematic content } \\
\text { analysis }\end{array}$ & Education; Bonding \\
\hline $\begin{array}{l}\text { Martins }{ }^{(30)} \text { et } \\
\text { al, } 2009\end{array}$ & $\begin{array}{l}\text { Revista de Enfermagem } \\
\text { da UERJ/ Brazil }\end{array}$ & Case study & $\begin{array}{l}\text { Semi-structured interview } \\
\text { based on previously } \\
\text { formulated script }\end{array}$ & $\begin{array}{l}\text { Discourse of the } \\
\text { collective subject }\end{array}$ & $\begin{array}{l}\text { Self-care; family; social } \\
\text { support network; bonding }\end{array}$ \\
\hline $\begin{array}{l}\text { Silval|(31) et al., } \\
2010\end{array}$ & $\begin{array}{l}\text { Revista de Saúde Pública/ } \\
\text { Brazil }\end{array}$ & Case study & $\begin{array}{l}\text { Documental analysis and } \\
\text { interviews }\end{array}$ & $\begin{array}{l}\text { Analysis of medical } \\
\text { records and interviews }\end{array}$ & $\begin{array}{l}\text { Self-care; bonding; } \\
\text { environment; specific needs }\end{array}$ \\
\hline $\begin{array}{l}\text { Ribeiro }^{(32)} \text { et } \\
\text { al., } 2014\end{array}$ & $\begin{array}{l}\text { Revista Enfermagem } \\
\text { Integrada/ Brazil }\end{array}$ & $\begin{array}{l}\text { Descriptive } \\
\text { study }\end{array}$ & $\begin{array}{l}\text { Interview script with } \\
\text { recording }\end{array}$ & $\begin{array}{l}\text { Readings of reports, } \\
\text { analysis, and data } \\
\text { categorization }\end{array}$ & $\begin{array}{l}\text { Self-care; education; } \\
\text { bonding; specific needs }\end{array}$ \\
\hline $\begin{array}{l}\text { Cardoso }^{(33)} \\
2011\end{array}$ & $\begin{array}{l}\text { Estudos interdisciplinares } \\
\text { de envelhecimento/ Brazil }\end{array}$ & $\begin{array}{l}\text { Experience } \\
\text { report }\end{array}$ & $\begin{array}{l}\text { Data recording and } \\
\text { evaluation of actions }\end{array}$ & Descriptive summary & $\begin{array}{l}\text { Self-care; education; health } \\
\text { promotion }\end{array}$ \\
\hline $\begin{array}{l}\text { Gago }^{(34)} \text {, } \\
\text { Lopes., } 2012\end{array}$ & $\begin{array}{l}\text { Acta Paulista de } \\
\text { Enfermagem/Brazil }\end{array}$ & $\begin{array}{l}\text { Grounded } \\
\text { Theory }\end{array}$ & $\begin{array}{l}\text { Non-participant } \\
\text { observation and semi- } \\
\text { structured interview }\end{array}$ & $\begin{array}{l}\text { Constant comparative } \\
\text { analysis method and } \\
\text { use of NVivo } 8^{\circledast} \text { Software }\end{array}$ & $\begin{array}{l}\text { Home environment; } \\
\text { bonding; health education; } \\
\text { family; visit type }\end{array}$ \\
\hline $\begin{array}{l}\text { Carvalhais, } \\
\text { Sousa }^{(35)}, 2013\end{array}$ & $\begin{array}{l}\text { Saúde Sociedade de São } \\
\text { Paulo/ Portugal }\end{array}$ & $\begin{array}{l}\text { Exploratory } \\
\text { study }\end{array}$ & Photovoice & $\begin{array}{l}\text { Content analysis by three } \\
\text { independent experts }\end{array}$ & $\begin{array}{l}\text { Healthy aging; bonding; } \\
\text { family; self-care }\end{array}$ \\
\hline
\end{tabular}


The developed actions had a diverse duration, but were beneficial to the participants, as well as efficient in improving self-care and the care provided, and increased the participation of the elderly in health promotion groups. Self-care is a manner of maintaining the independence of the elderly individual, even when he is debilitated by some chronic condition ${ }^{(20,22,25)}$. Thus, health promotion groups also stand out for making people's knowledge known, and for expanding the social support network, promoting changes in the quality of life of the elderly by means of interpersonal interaction ${ }^{(36-37)}$.

One study ${ }^{(24)}$ identified the following factors that most influenced the need for home visits by the nursing professional: being male, dependent for activities of daily living, having pressure injuries, and receiving emergency medical care at home. In contrast, according to the study, patients with severe cognitive impairment are less likely to receive home visits, and those with a pressure injury are four times more likely to require home visits. This study supports us in the management of cases and in the development of programs for this type of visit, as it identifies possible demands and outlines a profile of the target population.

Acting in environments where the elderly feel safer and more comfortable can have an even better impact; home interventions influence daily life to the point of changing eating habits, interfering with medication use, and encouraging the practice of physical activities. It can also arouse critical thought regarding fall prevention ${ }^{(38)}$.

Health education is one of the actions most accomplished by nurses. It is an important tool for self-improvement, with automatic and positive influences in the community. The educational development of community nurses enables effective meetings, which promote the self-efficacy and clinical outcomes of the elderly with chronic conditions. Health education also provides other benefits for the elderly, such as the reduction of depressive/anxious symptoms, and an improvement in cognitive performance ${ }^{(28,39)}$.

The important role of nursing in health promotion and active aging was evidenced in the authors' conclusions, which described satisfactory and positive outcomes. The described actions were performed in several environments, ranging from homes to hospitals ${ }^{(27)}$.

In general, qualitative studies corroborate the quantitative findings, especially regarding the importance of educational actions in home care for the elderly ${ }^{(29,32-33)}$, the perception about the contributions of the home environment ${ }^{(29-31,34-35)}$, and the relevance of the role of nursing in this context, based on the careful planning of care for the elderly (29,31-35).

The themes identified in the analyzed studies were grouped and arranged in the health work process model. The authors of this study identified and named the components of the health work process as follows: object, purpose, instruments, and, agents ${ }^{(40)}$.

Thus, the themes identified in the 16 articles were related to the object of the work process and, in this item, we note that the elderly person has excelled as the object of constituted care. Providing care begins with identification of the elderly individual, as a center to be perceived in his family and community context, with his specific characteristics, peculiarities, needs and possibilities. In home care, the planned care should begin with and be completed for the elderly individual. Thus, by centralizing the care provided to the elderly, we initiate an essential technological innovation in care, focusing on light technology using humanization, welcoming, and empowerment ${ }^{(41-42)}$.
In the context of home care, the elderly individual occupies a fundamental role: in addition to being the object of care, he acts as an agent, because his active participation in providing his own care is indispensable and determinant. Thus, the component related to the agents is now composed primarily by the elderly. Next, we highlight the family, as the agent that directly mediates the environment and the conditions in which the elder will be integrated, favoring or hindering his decision-making. The family members are characterized as informal caregivers, and their actions directly influence the quality of care provided to the elder. Finally, in the composition of the agents, we identified the health professionals as elements external to the family environment, and responsible for the establishment of evidence-based care. They should also propose specific goals for recovery, health promotion, and disease prevention ${ }^{(30,34-35)}$.

We also identified some important aspects with regards to the instruments needed for care in this context. Instruments are the resources used by agents with the purpose of transforming the object of care. Thus, in the articles included ${ }^{(29-35)}$, three instruments were found as basic for the care of the elderly in a home environment. The first one was the educational process, which is divided into three directions: the first directly influences the elder, as it includes the process of strengthening his autonomy. The other direction is represented by the family, recognized as an agent in the process of care provision, as it directly interferes in decision-making in the family environment. Finally, there is education with the professionals involved, whose objective is to enable them for specific care ${ }^{(43-46)}$.

The purpose component represents the intentionality of the whole process as it is initiated, and which is determined by the choices made. In the elderly, the purpose is the priority, as the aging process is identified as a constantly changing variable. Care without adequate planning can, therefore, only briefly solves a problem, but the failure to identify the primary cause poses risks in the medium- and long-term.

Therefore, studies indicate that it is necessary to meet the specific needs of the elderly, without compromising their healthy aging. The research also showed that the ultimate goal of care for the elderly in the home environment should be the maintenance of their functional capacities, with the preservation of their autonomy. This should be the nurse's intentionality in the planning of care for all situations, regardless of whether it is the first visit, a segment evaluation, or an emergency intervention (31-32,35).

We also detected the importance of the nursing team relationship with the elderly person in the home environment, basically characterized by a continuous interaction, capable of developing feelings of trust or distrust. Thus, the power of this interaction will be directly proportional to the quality of the information flow, that will support the planning and execution of care. In addition to the interaction, the studies highlighted the need for careful planning for care education, which can involve all participants in the process, including the elderly individuals themselves, to enable them to make decision for their day to day lives ${ }^{(29-32,35)}$.

This analysis showed that all the variables and themes identified were dynamically and consistently related to information feedback, knowledge, and attitudes, with rotation of the protagonist, but always having the elderly individual as an objective and guideline for providing care in the home environment. 
Assumptions of good practices in home care for the elderly: a systematic review Rodrigues RAP, Bueno AA, Casemiro FG, Cunha AN, Carvalho LPN, Almeida VC, et. al.

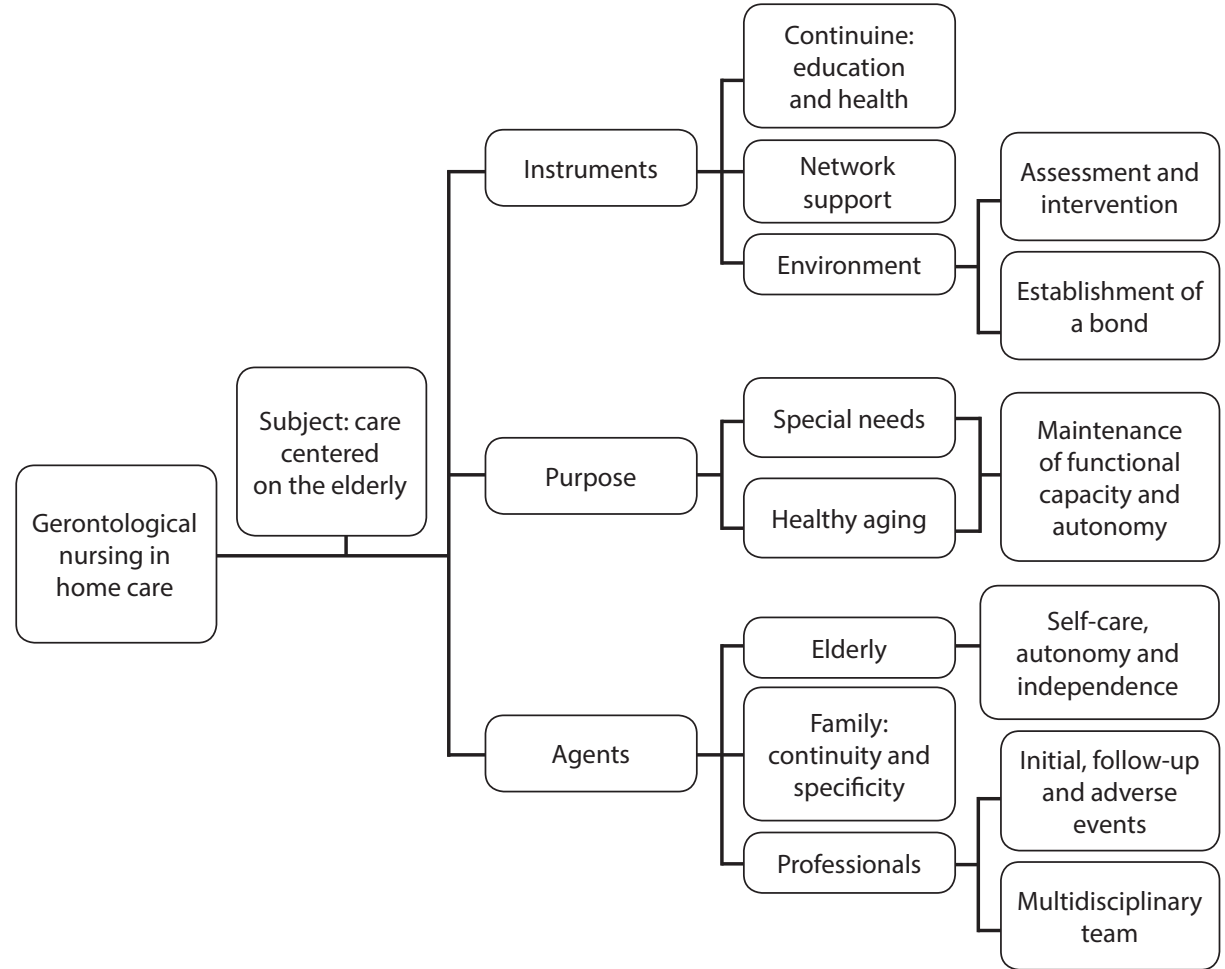

Figure 2- Assumptions for good practices in gerontological nursing in home care, 2018

In addition, as the health systems have prioritized health care at a lower cost and in the person's own environment, we consider that the development of good practices in home care for the elderly meets the need for a market that has limited financial resources.

Nursing practice is based on the interaction and articulation with other health professionals, in a model of multiprofessional performance that demands flexible professional protagonism. In this context, proposals to implement care protocols based on the use of different methods and techniques are essential for advances in this area.

\section{FINAL CONSIDERATIONS}

This review demonstrated the need for including the elderly individual and his family in the planning of gerontological home care nursing, because this favors the provision of

Next, Figure 2 presents a representation of the synthesis, both narrative and thematic. Despite the heterogeneity of the articles, common thematic categories were identified, which enabled us to align the results and present a meta-aggregative scheme of those most cited ${ }^{(13)}$.

\section{Study limitations}

The results of this review are based on the analysis of the 16 articles and show us that gerontological nursing needs to move forward with proposals of good actions to care for the elderly in their home environments. In general, the qualitative publications on the subject still need more methodological rigor in terms of the definition of the theoretical reference and analysis.

\section{Contributions to gerontological nursing and elderly health}

The increase in the elderly population predicted for this century denotes a period of reorganization of the society, including the health system and nursing care. Nurses, as care managers, should be prepared for this new demand. The development of research with the objective of promoting good home care practices will be fundamental to increasing knowledge, but the instruments of work should be based on different technologies of care, so that people can grow old and live in their homes with comfort and security. care effectively focused on the needs of the elderly person, and enables him to adapt to the family environment and the possibilities of collaboration of those with whom he shares the same space. The results of the analyzed studies show that this type of care also contributes to the strengthening of ties between the elderly individual and his relatives.

With regards to the adherence and continuity of the proposed intervention, health education plays a fundamental role, because it allows all involved to understand and choose to participate in the process of caring. In this way, establishing health education planning enables the empowerment of the elderly, strengthening their autonomy and independence, and training their families and informal caregivers, so that they feel secure in the decisions and actions they must take.

Good practices in gerontological home care nursing, according to the evidence, essentially depend on careful planning and organization, so that they are dynamic, inclusive, and contextualized. Thus, the production of care will be based on and guided by the elderly, based on their specific and global needs, which will favor a healthy and active aging process.

We conclude that researchers in this area of knowledge need to use research methods that offer more applicable results, and should use the theory of self-care related to autonomy and independence of the elderly, which favors active and healthy aging.

\section{REFERENCES}

1. Chibante CL, Santos TD, Valente GC. Santo FHE. O gerenciamento do cuidado de enfermagem aos clientes idosos: a busca por evidências. Rev Enferm UFPE [Internet]. 2016[cited 2018 May 10];848-58. Available from: https://repositorio.ufpe.br/handle/123456789/28392

2. Fuhrmann AC, Bierhals CCBK, Santos NO, Paskulin LMG. Associação entre a capacidade funcional de idosos dependentes e a sobrecarga 
Assumptions of good practices in home care for the elderly: a systematic review Rodrigues RAP, Bueno AA, Casemiro FG, Cunha AN, Carvalho LPN, Almeida VC, et. al.

do cuidador familiar. Rev Gaúcha Enferm [Internet]. 2015[cited 2018 May 09];14-20. Available from: http://www.scielo.br/pdf/rgenf/v36n1/ pt_1983-1447-rgenf-36-01-00014.pdf

3. Tahan J, Carvalho ACD. Reflexões de idosos participantes de grupos de promoção de saúde acerca do envelhecimento e da qualidade de vida. Saúde Soc[Internet]. 2010[cited May 11];19(4):878-88. Available from: http://www.scielo.br/pdf/sausoc/v19n4/14.pdf

4. Agencia Nacional de Vigilância Sanitária-ANVISA. Resolução Da Diretoria Colegiada - RDC №. 63. Dispõe sobre os Requisitos de Boas Práticas de Funcionamento para os Serviços de Saúde[Internet]. 2011 [cited 2018 May 11]. Available from: http://portal.anvisa.gov.br/ documents/33880/2568070/rdc0063_25_11_2011.pdf/94c25b42-4a66-4162-ae9b-bf2b71337664

5. Presidência da República (BR). Casa Civil. Política Nacional do Idoso (PNI). lei № 8.842[Internet]. De 4 de Janeiro de 1994[cited 2018 May 10]. Available from: http://www.planalto.gov.br/ccivil_03/leis//8842.htm

6. Constituição Da Republica Federativa Do Brasil. Capítulo VII. Art 230. Da Família, da Criança, do Adolescente e do Idoso[Internet]. 1988[cited 2018 May 09]. Available from: http://www.scielo.br/pdf/ep/v36n2/a04v36n2.pdf

7. Almeida L, Bastos PRHO. Autocuidado do Idoso: revisão sistemática da literatura. Rev ESPACIOS[Internet]. 2017[cited 2018 May 10];1015(38). Available from: https://www.revistaespacios.com/a17v38n28/a17v38n28p03.pdf

8. Wichmann FMA, Couto AN, Areosa SVCE, Montañés MCM. Grupos de convivência como suporte ao idoso na melhoria da saúde. Rev Bras Geriatr Gerontol[Internet]. 2013[cited 2018 May 10];16(4):821-32. Available from: http://www.scielo.br/pdf/rbgg/v16n4/1809-9823rbgg-16-04-00821.pdf

9. Little MO, Rantz M, Lynn GA. Health information technology in longer-term care: potential for the future. J Am Med Dir Assoc[Internet]. 2016[cited 2018 May 12];17:379-80. Available from: https://www.jamda.com/article/S1525-8610(16)00129-8/pdf

10. Lattanzio F, Abbatecola AM, Bevilacqua R, Chiatti C, Corsonello A, Rossi L. Advanced technology care innovation for older people in Italy: necessity and opportunity to promote health and wellbeing. J Am Med Dir Assoc[Internet]. 2014[cited 2018 May 10];15:457-66. Available from: https://www.sciencedirect.com/science/article/pii/S1525861014002096?via\%3Dihub

11. Morley JE. The Future of Long-Term Care. Divisions of Geriatric Medicine and Endocrinology, Saint Louis University school of Medicine, St. Louis, MO. JAMDA[Internet]. 2017[cited 2018 May 11];1-7. Available from: https://www.sciencedirect.com/science/article/pii/ S1525861016304984?via\%3Dihub

12. Brito MCC, Freitas CASL, Mesquita KO, Lima GK. Envelhecimento populacional e os desafios para a saúde pública: análise da produção científica. Rev Kairós Gerontol[Internet]. 2013[cited 2018 May 02]:16(2):161-78. Available from: https://revistas.pucsp.br/index.php/kairos/ article/view/18552

13. Aromataris E, Munn Z, Briggs J. Institute Reviewer's Manual[Internet]. The Joanna Briggs Institute; 2017[cited 2018 May 09]. Available from: https://www.researchgate.net/profile/Micah_Peters2/publication/319713049_2017_Guidance_for_the_Conduct_of_JBI_Scoping_Reviews/ links/59c355d40f7e9b21a82c547f/2017-Guidance-for-the-Conduct-of-JBI-Scoping-Reviews.pdf

14. Moola SMZ, Tufanaru C, Aromataris E, Sears K, Sfetcu R, Currie M. et al . Systematic reviews of etiology and risk. Joanna Briggs Institute Reviewer's Manual[Internet]. The Joanna Briggs Institute; 2017[cited 2018 May 07]. Available from: https://wiki.joannabriggs.org/display/ MANUAL/Chapter+7\%3A+Systematic+reviews+of+etiology+and+risk

15. Ouzzani M, Hammady H, Fedorowicz Z, Elmagarmid A. Rayyan: a web and mobile app for systematic reviews. Syst Rev[Internet]. 2016[cited 2018 May 07];5(1):210. Available from: https://www.ncbi.nlm.nih.gov/pmc/articles/PMC5139140/pdf/13643_2016_Article_384.pdf

16. Shamseer L, Moher $D, C$ larke $M$, Ghersi D, Liberati A, Petticrew $M$, et al. Itens de relatórios preferidos para protocolos de revisão sistemática e metaanálise (PRISMA-P) 2015: elaboração e explicação. BMJ[Internet]. 2015[cited 2018 May 07]:349-7647. Available from: http://www.scielo. $\mathrm{br} / \mathrm{pdf} / \mathrm{ress} / \mathrm{v24n2/2237-9622-ress-24-02-00335.pdf}$

17. Ursi ES, Galvão CM. Prevenção de lesões de pele no perioperatório: revisão integrativa da literatura. Rev Latino-Am Enfermagem[Internet]. 2006[cited 2018 May 07];14(1):124-31. Available from: http://www.scielo.br/pdf/rlae/v14n1/v14n1a17.pdf

18. Ministério da Saúde (BR). Conselho Nacional de Saúde. Resolução n 510, de 7 de abril de 2016[Internet]. Diário Oficial da República Federativa do Brasil, Brasília, DF, 24 de maio de 2016. Seção 1. 44-46. Available from: http://conselho.saude.gov.br/resolucoes/2016/ Reso510.pdf

19. Critical Appraisal Skills Programme. CASP checklist[Internet]. Oxford: CASP. 2014[cited 2018 May 07]. Available from: https://casp-uk.net/ casp-tools-checklists/.

20. Griffiths R, Johnson M, Piper M, Langdon R. A nursing intervention for the quality use of medicines by elderly community clients. Int J Nurs Pract[Internet]. 2004[cited 2018 May 12]. 10(4):166-76. Available from: https://onlinelibrary.wiley.com/doi/ epdf/10.1111/j.1440-172X.2004.00476.x

21. Marek KD, Popejoy L, Petroski G, Rantz M. Nurse care coordination in community-based long-term care. J Nurs Scholars[Internet]. 2006[cited 2018 May 12];38(1):80-6. Available from: https://sigmapubs.onlinelibrary.wiley.com/doi/epdf/10.1111/j.1547-5069.2006.00081.x

22. Park E, Kim J. The impact of a nurse-led home visitation program on hypertension self-management among older community-dwelling Koreans. Public Health Nurs[Internet]. 2016[cited 2018 May 12];33(1):42-52. Available from: https://onlinelibrary.wiley.com/doi/ pdf/10.1111/phn.12220

23. Badia JG, Santos BA, Segura JCC, Casellas MDC, Lombardo FC, Tebar AH, et al. Nursing workload predictors in Catalonia (Spain): a home care cohort study. Gac Sanit[Internet]. 2011 [cited 2018 May 12];25(4):308-13. Available from: http://scielo.isciii.es/pdf/gs/v25n4/original7.pdf 
Assumptions of good practices in home care for the elderly: a systematic review Rodrigues RAP, Bueno AA, Casemiro FG, Cunha AN, Carvalho LPN, Almeida VC, et. al.

24. Vilas Boas PJF, Souza ML, Augusto MC, Floripes TM. Acompanhamento domiciliar de idoso de Unidade da Saúde da Família de Botucatu. Rev Bras Educ Med[Internet]. 2012[cited 2018 May 12];36(1):161-5. Available from: http://www.scielo.br/pdf/rbem/v36n1s1/v36n1s1a22.pdf

25. Karlsson S, Edberg AK, Jakobsson ULF, Hallberg IR. Care satisfaction among older people receiving public care and service at home or in special accommodation. J Clin Nurs[Internet]. 2013[cited 2018 May 12];318-30. Available from: https://onlinelibrary.wiley.com/doi/ epdf/10.1111/jocn.12115

26. Markle-Reid M, Weir R, Browne G, Roberts J, Gafni A, Henderson S. Health promotion for frail older home care clientes. J Adv Nurs[Internet]. 2006[cited 2018 May 12];54(3):381-39. Available from: https://onlinelibrary.wiley.com/doi/epdf/10.1111/j.1365-2648.2006.03817.x

27. Moraes GLA, Borges CL, Oliveira ET, Sarmento LR, Araújo PR, Silva MJ. Aplicação de protocolo de prevenção de úlcera por pressão no contexto domiciliar: uma trajetória percorrida. Cogitare Enferm[Internet]. 2013[cited 2018 May 12];18(2):387-91. Available from: https:// revistas.ufpr.br/cogitare/article/view/32590

28. Cooper J, McCarter KA. The development of a community and home-based chronic care management program for older adults. Public Health Nurs[Internet]. 2013[cited 2018 May 12];31:36-43. Available from: https://onlinelibrary.wiley.com/doi/pdf/10.1111/phn.12049

29. Rodrigues RAP, Casagrande, LDR. Atividade educativa com as idosas que tiveram queda e seus cuidadores: atuação da enfermeira geriátrica no domicílio. Acta Paul Enferm. 1996;9(1):80-91.

30. Martins JJ, Nascimento ERP, Erdmann AL, Candemil MC, Belaver GM. Cuidado no contexto domiciliar: o discurso de idosos/familiares e profissionais. Rev Enferm[Internet]. 2009[cited 2018 May 12];17(4):556-62. Available from: http://www.facenf.uerj.br/v17n4/v17n4a18.pdf

31. Silva KL, Sena RR, Seixas CT, Feuerwerker LCM, Merhy EE. Atenção domiciliar como mudança do modelo tecnoassistencial. Rev Saúde Pública [Internet]. 2010[cited 2018 May 12];44(1):166-76. Available from: http://www.scielo.br/pdf/rsp/v44n1/18.pdf

32. Ribeiro AP. Atuação do enfermeiro da estratégia saúde da família na atenção à saúde do idoso. Rev Enferm Integrada, Minas Gerais[Internet]. 2011 [cited 2018 May 12];4(2):779-92. Available from: https://www.unileste.edu.br/enfermagemintegrada/artigo/v4_2/01ATUACAO-DO-ENFERMEIRO-DA-ESTRATEGIA-SAUDE-DA-FAMILIA-NA-ATENCAO-A-SAUDE-DO-IDOSO(RIBEIRO;PIRES).pdf

33. Cardoso CMC, Marion D, Wichmann FMA, Luzzi G, Benitez LB, Franco M, et al. Atendimento à Unidade Familiar do Idoso: experiência multidisciplinar. Est Interdisc Envelhecimento[Internet]. 2011 [cited 2018 May 12];16:385-394. Available from: https://seer.ufrgs.br/ RevEnvelhecer/article/view/9933/0

34. Gago EA, Lopes MJ. Cuidados domiciliares: interação do enfermeiro com a pessoa idosa/família. Acta Paul Enferm[Internet]. 2012 [cited 2018 May 12];25(1):74-80. Available from: http://www.scielo.br/pdf/ape/v25nspe1/pt_12.pdf

35. Carvalhais M, Sousa L. Qualidade dos cuidados domiciliares em enfermagem a idosos dependentes. Saude Soc[Internet]. 2013 [cited 2018 May 12];22(1):160-72. Available from: http://www.scielo.br/pdf/sausoc/v22n1/15.pdf

36. Gomes LB, Merhy EE. Understanding Popular Health Education: a review of the Brazilian literature. Cad Saúde Pública[Internet]. 2011 [cited 2018 May 14];27(1):7-18. Available from: http://www.scielo.br/pdf/csp/v27n1/02.pdf

37. Guedes M, Barbosa OG, Lima KC, Caldas CP, Veras RP. Apoio social e o cuidado integral à saúde do idoso. Physis[Internet]. 2017 [cited 2018 May 14];27(4):1185-204. Available from: http://www.scielo.br/pdf/physis/v27n4/0103-7331-physis-27-04-01185.pdf

38. Nogueira IS, Previato GF, Scolari GA, Gomes ACO, Carreira L, Baldissera VDA. Intervenção domiciliar como ferramenta para o cuidado de enfermagem: avaliação da satisfação de idosos. Rev Gaucha Enferm [Internet]. 2016[cited 2018 May 12];37(N.Spe):e68351. Available from: http://www.scielo.br/pdf/rgenf/v37nspe/en_0102-6933-rgenf-1983-14472016esp68351.pdf

39. Casemiro FG, Quirino DM, Diniz MAA, Rodrigues RAP, Pavarini SI, Gratão ACM. Effects of health education in the elderly with mild cognitive impairment. Rev Bras Enferm[Internet]. 2018[cited 2018 May 14];71(2):801-10. Available from: http://www.scielo.br/pdf/reben/v71s2/00347167-reben-71-s2-0801.pdf

40. Pereira IB, Lima JCF. Dicionário de Educação Profissional em Saúde[Internet]. 2009[cited 2018 May 14]. Rio de Janeiro: Editora Fiocruz. $2^{\text {a }}$ edição. Available from: http://www.epsjv.fiocruz.br/printpdf/55

41. Paranhos DGAM, Albuquerque A, Garrafa V. Vulnerabilidade do paciente idoso à luz do princípio do cuidado centrado no paciente. Saúde Soc[Internet]. 2017[cited 2018 May 12];26(4):932-42. Available from: http://www.scielo.br/pdf/sausoc/v26n4/1984-0470-sausoc-26-04-932.pdf

42. Santos WJ, Giacomin KC. Avaliação da tecnologia das relações de cuidado nos serviços em saúde: percepção dos idosos inseridos na Estratégia Saúde da Família em Bambuí, Brasil[Internet]. 2014[cited 2018 May 14]. Available from: http://www.scielo.br/pdf/csc/v19n8/14138123-csc-19-08-03441.pdf

43. Cerqueira AF, Nunes L. Uma matriz referencial para a educação com focona pessoa ao envelhecer. Rev Ibero-Am Saúde[Internet]. 2017[cited 2018 May 14];3(3). Available from: http://www.revistas.uevora.pt/index.php/saude_envelhecimento/article/view/238

44. Silva HS, Gutierrez BA. A educação como instrumento de mudança na prestação de cuidados para idosos. Educ Rev[Internet]. 2018[cited 2018 May 14];34(67):283-96. Available from: http://www.scielo.br/pdf/er/v34n67/0104-4060-er-34-67-283.pdf

45. Almeida SR, Martins MRA, Amendola F, Martins RS, Hitomi YC, Campos MA. Vulnerabilidade de famílias de idosos assistidos pela Estratégia Saúde da Família. Rev Bras Enferm[Internet]. 2015[cited 2018 May 15];68(2):244-52. Available from: http://www.scielo.br/pdf/reben/v68n2/ en_0034-7167-reben-68-02-0244.pdf

46. Correa RGCF, Santos RAASS, Rolim ILTP, Coutinho NPS. Atenção no cuidado ao idoso: infantilização e desrespeito à autonomia na assistência de enfermagem. Rev Pesqui Saúde[Internet]. 2016[cited 2018 May 14];17(3). Available from: http://www.scielo.br/pdf/rbgg/v22n1/pt_18099823-rbgg-22-01-e180197.pdf 